\title{
Genetic influences on right ventricular systolic pressure (RVSP) in chronic obstructive pulmonary disease (COPD)
}

\author{
Janet G Shaw ${ }^{1,3^{*}}$, Annette G Dent ${ }^{1,3}$, Linda H Passmore ${ }^{1}$, Darryl J Burstow ${ }^{2}$, Rayleen V Bowman ${ }^{1,3}$,
} Paul V Zimmerman ${ }^{1,3}$, Kwun M Fong ${ }^{1,3}$ and lan A Yang ${ }^{1,3}$

\begin{abstract}
Background: Pulmonary hypertension (PH) is a complication of chronic obstructive pulmonary disease (COPD). This study examined genetic variations in mediators of vascular remodelling and their association with $\mathrm{PH}$ in patients with COPD. In patients with COPD, we genotyped 7 SNPs in 6 candidate PH genes (NOS3, ACE, EDN1, PTGIS, SLC6A4, VEGFA). We tested for association with right ventricular systolic pressure (RVSP), spirometry and gas transfer, and hypoxemia.

Methods: In patients with COPD, we genotyped 7 SNPs in 6 candidate PH genes (NOS3, ACE, EDN1, PTGIS, SLC6A4, VEGFA). We tested for association with right ventricular systolic pressure (RVSP), spirometry and gas transfer, and hypoxemia.

Results: 580 COPD patients were recruited, 341 patients had a transthoracic echocardiogram, with RVSP measurable in 278 patients (mean age 69 years, mean FEV $150 \%$ predicted, mean RVSP 44 mmHg, median history of 50 packyears). Of the 7 tested SNPs, the NOS3-VNTR polymorphism was significantly associated with RVSP in a dosedependent fashion for the risk allele: mean RVSP for a/a and a/b genotypes were 52.0 and $46.6 \mathrm{mmHg}$ respectively, compared to $43.2 \mathrm{mmHg}$ for $\mathrm{b} / \mathrm{b}$ genotypes $(P=0.032)$. No associations were found between RVSP and other polymorphisms. ACE II or ID genotypes were associated with a lower $\mathrm{FEV}_{1} \%$ predicted than the ACE DD genotype ( $P$ = 0.028). The NOS3-298 TT genotype was associated with lower KCO \% predicted than the NOS3-298 GG or GT genotype $(P=0.031)$.

Conclusions: The NOS3-VNTR polymorphism was associated with RVSP in patients with COPD, supporting its involvement in the pathogenesis of PH in COPD. ACE and NOS3 genotypes were associated with COPD disease severity, but not with the presence of PH. Further study of these genes could lead to the development of prognostic and screening tools for PH in COPD.
\end{abstract}

Keywords: COPD, Pulmonary hypertension, Genetic polymorphism

\section{Background}

Pulmonary hypertension (PH) is a serious complication of chronic obstructive pulmonary disease (COPD) and develops in $30 \%$ to $70 \%$ of patients with COPD, increasing their morbidity and mortality [1]. $\mathrm{PH}$ is progressive in COPD, with mean pulmonary arterial pressure

\footnotetext{
*Correspondence: Janet_Shaw@health.qld.gov.au

'Department of Thoracic Medicine, The Prince Charles Hospital, Rode Rd,

Chermside, Brisbane QLD 4032, Australia

${ }^{3}$ School of Medicine, The University of Queensland, St Lucia, Brisbane QLD4067, Australia

Full list of author information is available at the end of the article
}

increasing over time $[2,3]$. Understanding variations in susceptibility to $\mathrm{PH}$ in patients with COPD could significantly enhance diagnosis, risk stratification and therapy for these patients.

Vascular remodelling is the main pathological feature in $\mathrm{PH}$ and is mediated via vasoactive molecules [4]. Genes encoding these mediators contain genetic polymorphisms that potentially affect their function and could influence $\mathrm{PH}$ in COPD [5-18]. Polymorphisms exist in vasodilator (nitric oxide synthase (NOS3) [8,13], prostacyclin synthase (PTGIS) [19]) and vasoconstrictor (angiotensin converting enzyme $(A C E)$ [17], endothelin-

\section{Biomed Central}


1 (ET1), serotonin transporter (SLC6A4) [14]) and vascular endothelial growth factor (VEGFA) [20] genes.

We hypothesised that genetic variation in genes encoding mediators acting on pulmonary vessels alters right ventricular systolic pressure (RVSP) in patients with COPD, even after adjustment for clinical factors associated with elevated RVSP. Additionally, we hypothesised that these polymorphisms are associated with COPD disease severity. We selected variants previously associated with vascular disease, in vasoactive mediators of biological importance in pulmonary hypertension.

\section{Methods}

\section{Participants}

Patients with a thoracic physician's diagnosis of COPD, based on chronic airflow limitation not fully reversible with bronchodilator [21], reduced gas transfer (KCO) and/or emphysema on CT scan, were recruited from thoracic clinics and wards of The Prince Charles Hospital (TPCH). Patients with other major respiratory diseases, including interstitial lung disease, lung cancer, pneumonia, cystic fibrosis, bronchiectasis, pleural effusion and lung surgery, were excluded. All participants gave written informed consent. This study was approved by the research ethics committees of TPCH (EC9865 and EC2108) and The University of Queensland (H372).

\section{Clinical phenotyping}

Participants completed a clinical questionnaire about their lung disease, symptoms, smoking history and ethnicity. One pack-year of smoking was defined as the equivalent of 20 cigarettes smoked per day for one year. Chronic bronchitis was defined as a cough with sputum production for at least 3 months in each of two consecutive years [21].

\section{Lung function tests}

Participants had lung function tests at recruitment, during their routine care at the hospital, whilst clinically stable. Lung function testing consisted of spirometry and single breath carbon monoxide diffusing capacity (DLCO) and performed according to American Thoracic Society/European Respiratory Society Taskforce (ATS/ ERS) standards [22-24]. Measurements were compared to predicted values $[25,26]$. The lung function parameters $\mathrm{FEV}_{1}$, slow vital capacity $(\mathrm{VC}), \mathrm{FEV}_{1} / \mathrm{VC}$ ratio and $\mathrm{KCO}$ were used to characterise COPD.

\section{Echocardiography}

A subgroup of patients had a transthoracic echocardiogram performed as a routine part of their clinical care, using standard techniques [27]. RVSP was calculated using the simplified Bernoulli equation. The pressure difference between the right ventricle and right atrium during systole is reflected by the velocity of the tricuspid regurgitation (TR) signal. RVSP can be estimated from right atrial pressure using the equation $\mathrm{RVSP}=4$ $\left(\mathrm{V}_{\mathrm{TR}}\right)^{2}+\mathrm{RAP}$, where $\mathrm{V}_{\mathrm{TR}}$ is peak TR velocity $(\mathrm{m} / \mathrm{s})$ and RAP is mean right atrial pressure $(\mathrm{mmHg})$. The mean RAP is estimated using inferior vena cava (IVC) size and reactivity as per American Society of Echocardiography (ASE) recommendations [28].

\section{Arterial blood gases}

Arterial blood gas (ABG) results were obtained from the patients' medical records. Arterial blood was drawn from the radial artery while the patients breathed room air.

\section{Genotyping}

Genomic DNA was extracted from peripheral blood using a modified salt extraction method [29]. Polymerase chain reaction (PCR) was used to genotype two polymorphisms, PCR with restriction fragment length polymorphism (RFLP) was used for three polymorphisms, and single base pair extension was used for one polymorphism (see Additional file 1: Table S1). PCR reactions were performed in a final volume of $20 \mu \mathrm{l}$ containing $10 \mathrm{ng}$ genomic DNA, $0.2 \mathrm{mM}$ of dNTPs, and $0.25 \mu \mathrm{M}$ of each of the forward and reverse primers. For five polymorphisms, $0.5 \mathrm{U}$ REDTaq DNA polymerase (Sigma, Saint Louis, Missouri, USA) and 10x REDTaq PCR reaction buffer were used. For the SLC6A4 polymorphism, 1.5 U HotStarTaq DNA polymerase (QIAGEN, Hilden, Germany) and 10x HotStar PCR reaction buffer were used, together with $5 \mathrm{x}$ Q-Solution. The PCR amplification was performed in a thermal cycler. Genotypes were determined by agarose gel electrophoresis of PCR products. Ethidium bromide was added to each gel at $1 \mu \mathrm{g} / \mathrm{ml}$ final concentration. The stained bands were visualised by the Molecular Imager FX (Bio-Rad, Hercules, California, USA). To ensure reproducibility, $10 \%$ of the samples were chosen randomly and repeated for each polymorphism; these genotypes were confirmed by this repeated testing.

The EDN1 gene polymorphism was genotyped by single base extension with alleles identified by direct mass measurement of the analyte using the SEQUENOM ${ }^{\mathrm{TM}}$ MassARRAY ${ }^{\circledR}$ system (MALDI-TOF mass spectrometry) at the Australian Genome Research Facility.

\section{Statistical methods}

SPSS (Statistical Package for the Social Sciences) for Windows Version 17.0 (SPSS Inc, Chicago Illinois, USA) was used. Hardy-Weinberg equilibrium was calculated using the $\chi^{2}$ test to compare expected $v s$ observed genotype frequencies. Associations of genotypes with RVSP or lung function were performed using ANOVA for additive genotype models ( $\mathrm{AA} v s \mathrm{AB} v s \mathrm{BB}$ ), and $t$-tests 
for dominant ( $\mathrm{AA} v s \mathrm{AB}+\mathrm{BB})$ and recessive $(\mathrm{AA}+\mathrm{AB}$ vs $\mathrm{BB}$ ) genotype models. Adjustment for clinical confounders was performed using multiple linear regression, in which genotypes and clinical covariates (age, gender, $\mathrm{BMI}, \mathrm{PaO}_{2}, \mathrm{FEV}_{1} \%$ predicted, $\mathrm{KCO} \%$ predicted) were independent variables, and RVSP was the dependent variable. Analyses were done for all available participants, and also with the subgroup of COPD patients with $\mathrm{FEV}_{1} / \mathrm{VC}<0.7$. In all analyses, a two-tailed $P$ value of $<0.05$ was considered significant.

For the $t$-test analyses of RVSP using dominant or recessive models, power calculations indicated that a total of 190 participants with RVSP measurements were required to detect a difference of $15 \%$ in mean RVSP in the cohort, with $80 \%$ power (based on mean RVSP of $44 \mathrm{mmHg}$, SD $13 \mathrm{mmHg}, P$ value of 0.05 , and ratio of genotype groups of at least 1:2, which was the case for all variants studied, except the NOS3 VNTR which had a lower ratio) (PS Power calculation program [30]). Power varied according to allele frequency and type of genetic analysis.

\section{Results}

\section{Participant characteristics}

580 patients with COPD were studied (Table 1); most were Caucasian males (only two of Asian ethnicity), with a mean age of 68 years. Chronic bronchitis was present in $35 \%$ of patients. All were current or former smokers, with the exception of six never smokers who nevertheless satisfied criteria for COPD. 514 patients (89\%) had moderate to severe airflow limitation (FEV1\% predicted $<80 \%$ ), with mean $\mathrm{FEV}_{1} 50 \%$ predicted. Gas transfer (KCO) was measured in $97 \%(561 / 580)$ of patients, and was below the lower limit of normal (75\% predicted) in

Table 1 Demographic characteristics of participants

\begin{tabular}{|c|c|c|c|c|}
\hline Characteristics & $\begin{array}{l}\text { All COPD } \\
\text { patients }\end{array}$ & $\begin{array}{l}\text { Subgroup with } \\
\text { RVSP results }\end{array}$ & $\begin{array}{l}\text { Subgroup without } \\
\text { measureable RVSP }\end{array}$ & $P$ value \\
\hline Males/Females & $364 / 216$ & $167 / 111$ & $42 / 21$ & \\
\hline$\%$ Males/\%Females & $63 / 37$ & $60 / 40$ & $67 / 33$ & \\
\hline Mean (SD) age at recruitment (yr) & $68.1(9.3)$ & $69.3(9.0)$ & $67.3(9.8)$ & 0.11 \\
\hline Range & $35.1-87.0$ & $38.3-87.0$ & $35.1-81.2$ & \\
\hline Median smoking history (pack years) & 50 & 50 & 47 & 0.93 \\
\hline$(\mathrm{IQR})$ & $(33.8-69.0)$ & $(31.5-69.0)$ & $(34.0-68.8)$ & \\
\hline Range & $0.0-186.0$ & $0.0-186.0$ & $8.5-172.5$ & \\
\hline Chronic bronchitis present (\% of total) & $201(35 \%)$ & $99(36 \%)$ & $26(41 \%)$ & 0.33 \\
\hline Mean (SD) FEV $1(\mathrm{~L})$ & $1.2(0.63)$ & $1.20(0.55)$ & $1.13(0.50)$ & 0.40 \\
\hline Range & $0.2-4.7$ & $0.2-3.9$ & 0.34-3.09 & \\
\hline Mean (SD) FEV $1 \%$ predicted & $50(21.8)$ & $50(20.8)$ & $44.5(18.1)$ & 0.062 \\
\hline Range & $7-129$ & $7-129$ & 11.4-89.3 & \\
\hline Mean (SD) VC (L) & $2.8(0.92)$ & $2.7(0.83)$ & $2.81(0.87)$ & 0.28 \\
\hline Range & $0.9-6.4$ & $0.9-5.6$ & $1.15-4.88$ & \\
\hline Mean (SD) VC (L) \% predicted & $77.3(17.8)$ & $76.0(17.4)$ & $75.5(16.6)$ & 0.88 \\
\hline Range & $28.5-132.3$ & 28.8-132.3 & 36.3-111.0 & \\
\hline Mean (SD) $\mathrm{FEV}_{1}$ NC ratio \% & $45(15)$ & $45(14)$ & 40.9 (13.5) & 0.026 \\
\hline Range & $7-80$ & $7-80$ & $17.5-67.9$ & \\
\hline Mean (SD) KCO (ml/min/mmHg/L) & $2.5(0.96)$ & $2.4(0.97)$ & $2.56(0.97)$ & 0.36 \\
\hline Range & $0.44-6.6$ & $0.44-6.6$ & $0.49-4.7$ & \\
\hline Mean (SD) KCO \% predicted & $58(22.5)$ & $58(23.4)$ & $59.8(22.4)$ & 0.60 \\
\hline Range & 9.8-134.5 & $12.6-134.5$ & 9.8-109.8 & \\
\hline Mean (SD) RVSP (mmHg) & $44.2(12.7)$ & $44.2(12.7)$ & Unable to & \\
\hline Range & 16.0-94.0 & 16.0-94.0 & measure & \\
\hline Mean (SD) $\mathrm{PaO}_{2}(\mathrm{mmHg})$ & 70.5 (11.6) & $69.4(11.8)$ & $71.7(11.5)$ & 0.23 \\
\hline Range & 35.0-99.0 & 35.0-99.0 & 53.0-95.0 & \\
\hline Mean (SD) $\mathrm{PaCO}_{2}(\mathrm{mmHg})$ & $41.3(7.7)$ & $41.6(8.1)$ & $40.8(7.7)$ & 0.49 \\
\hline Range & $26.0-76.0$ & $27.0-76.0$ & $26.0-62.0$ & \\
\hline Mean (SD) BMI $\left(\mathrm{kg} / \mathrm{m}^{2}\right)$ & $25.0(5.5)$ & $24.9(5.3)$ & $26.0(5.5)$ & 0.14 \\
\hline Range & $13.0-46.1$ & $13.5-44.0$ & $15.9-46.1$ & \\
\hline
\end{tabular}


$78 \%$ (437/561). Mean gas transfer (KCO \% predicted) was 58\%. ABG results were obtained for 271 patients who also had a measureable RVSP, $81 \%$ of the patients had an ABG within 12 months of their echocardiogram.

\section{Echocardiography}

Echocardiography was performed in 341 of the 580 (59\%) patients. RVSP was measurable in 278 of the 341 patients who had an echocardiogram (82\% of total 341$)$. The demographic characteristics of patients who had echocardiography did not differ significantly from those of patients with no echocardiography. Echocardiography was performed but no RVSP measurement was possible in 63 patients either because there was no tricuspid regurgitation or the echocardiogram was technically difficult and echo signals could not be obtained. Demographic and disease characteristics were similar between patients with and without measurable RVSP, except for a lower $\mathrm{FEV}_{1} / \mathrm{VC}$ ratio in those without measurable RVSP. Both these subgroups had similar characteristics to the whole cohort (Table 1). RVSP measurements ranged from 16 to $94 \mathrm{mmHg}, 115$ patients were within the normal range chosen for this study (15-39 $\mathrm{mmHg})$ and 163 patients (59\%) had RVSP $\geq 40 \mathrm{mmHg}$ [31].

Data on the left ventricular ejection fraction (EF), mitral valve and aortic valve were collected for each patient. 13 patients had missing EF measurements and 6 patients had missing information on both mitral and aortic valves. A normal EF (>50\%) was recorded for 275 (80\% of 328) of the patients (range 11\% - 82\%, mean (SD) 59\% (12.2)). $60 \%$ (205 of 335) of the patients had a normal mitral valve, with 123 (36\%) having some degree of mitral regurgitation (of whom 38 had moderate to severe mitral regurgitation), 5 (1.5\%) having mitral stenosis (of whom 3 had moderate to severe mitral stenosis) and 2 (0.6\%) having both. A normal aortic valve was found in 48\% (165 of $335)$ of the patients, 103 (30\%) had aortic valve sclerosis, 54 (16\%) had aortic regurgitation (of whom 14 had moderate to severe aortic regurgitation) and 13 (3.8\%) had aortic stenosis (of whom 7 had moderate to severe aortic stenosis).

\section{Genotypes}

$98.6 \%$ to $100 \%$ of all the patients were successfully genotyped by the PCR or PCR-RFLP methods, and the EDN1 polymorphism had a $95.7 \%$ success rate using the single base extension method. The distribution of the genotypes for 6 of the 7 polymorphisms were in HardyWeinberg equilibrium (HWE), with the exception being NOS3-Glu298Asp SNP which deviated from HWE $(P=0.02)$.

\section{Association of genotypes with RVSP measurements}

One-way ANOVA was used to test the relationship between genotype and RVSP (Table 2). There was a significant association between RVSP and NOS3-VNTR SNP genotypes $(P=0.032)$, with highest mean RVSP in patients with 4aa genotype of the VNTR. There were no statistically significant associations with RVSP for SNP genotypes of other genes tested (VEGFA, ACE, SLC6A4, PTGIS, NOS3-298 and EDN1). The distribution of genotypes in the subgroup of COPD patients with a RVSP measurement were in agreement with the HWE predicted frequencies except for EDN1 $(P=0.04)$.

When considering only those COPD patients with FEV1/VC $<0.7 \quad(\mathrm{n}=263)$, the NOS3-VNTR SNP genotype association remained statistically significant in a $t$-test analysis (4bb, mean (SD) $43.5 \mathrm{mmHg}$ (11.8), $\mathrm{n}=186$ vs $4 \mathrm{ab} / 4 \mathrm{aa}$, mean (SD) $47.1 \mathrm{mmHg}$ (14.6) $\mathrm{n}=77, P=0.034$ ).

\section{Association of clinical factors with RVSP measurements}

Clinical factors potentially confounding the association of genotypes with RVSP include arterial $\mathrm{PaO}_{2}, \mathrm{FEV}_{1} \%$ predicted, $\mathrm{KCO} \%$ predicted and $\mathrm{FEV}_{1} / \mathrm{VC}$ ratio, all of which showed weak inverse correlations with RVSP (Table 3).

\section{Association of genotypes with lung function impairment}

To detect disease-modifying effects of the candidate SNPs one-way ANOVA analyses were performed between genotypes and $\mathrm{FEV}_{1}$ (\% predicted) and $\mathrm{KCO}(\%$ predicted). No significant associations were found (Tables 4 and 5).

\section{Linear regression modelling of associations with RVSP measurements}

Multiple linear regression modelling was used to test whether genotypes associated with RVSP remained significantly associated, when controlled for clinical factors. Arterial $\mathrm{PaO}_{2}$ and $\mathrm{KCO} \%$ predicted were significantly associated with RVSP in all analyses (see Additional file 1: Table S2). The association with NOS3-VNTR, as grouped genotypes $4 \mathrm{aa}+4 \mathrm{ab}$ vs $4 \mathrm{bb}$, remained significantly associated with RVSP, even when controlling for the clinical factors (see Additional file 1: Table S3).

\section{Additional genetic modelling}

Patients with the NOS3-VNTR 4aa or 4ab genotypes had significantly higher RVSP levels than the NOS3-VNTR 4bb genotype (see Additional file 1: Table S3). There were no other significant differences observed between genotypes and RVSP when using dominant and recessive genetic models. The $A C E$ II or ID genotypes were associated with a significantly lower $\mathrm{FEV}_{1} \%$ predicted than the DD genotype $(P=0.028)$ (see Additional file 1 : Table 
Table 2 Association of genotypes with RVSP measurements in COPD patients with an RVSP measurement, using ANOVA

\begin{tabular}{|c|c|c|c|c|c|}
\hline Gene & Genotypes & Number & $\begin{array}{l}\text { Mean RVSP } \\
(\mathrm{mmHg})\end{array}$ & $\begin{array}{l}\text { Standard } \\
\text { Deviation }\end{array}$ & $P$ value \\
\hline \multirow[t]{4}{*}{$\overline{V E G F A}$} & GG & 123 & 42.8 & 12.0 & 0.24 \\
\hline & $\overline{G C}$ & 117 & 45.2 & 13.6 & \\
\hline & $\overline{C C}$ & 38 & 46.0 & 12.1 & \\
\hline & & Total 278 & 44.2 & 12.7 & \\
\hline \multirow[t]{4}{*}{ NOS3-VNTR } & $4 \mathrm{bb}$ & 199 & 43.2 & 11.8 & 0.032 \\
\hline & $4 a b$ & 70 & 46.6 & 13.8 & \\
\hline & $4 a a$ & 8 & 52.0 & 20.2 & \\
\hline & & Total 277 & 44.3 & 12.7 & \\
\hline \multirow[t]{4}{*}{$A C E$} & $\|$ & 69 & 45.6 & 14.2 & 0.61 \\
\hline & $\overline{I D}$ & 139 & 44.0 & 12.5 & \\
\hline & $\overline{\mathrm{DD}}$ & 69 & 43.6 & 11.6 & \\
\hline & & Total 277 & 44.3 & 12.7 & \\
\hline \multirow[t]{4}{*}{$\overline{S L C 6 A 4}$} & $\mathrm{LL}$ & 90 & 42.7 & 12.6 & 0.43 \\
\hline & $\overline{\mathrm{LS}}$ & 131 & 44.8 & 13.2 & \\
\hline & SS & 53 & 45.1 & 11.3 & \\
\hline & & Total 274 & 44.2 & 12.6 & \\
\hline \multirow[t]{4}{*}{ PTGIS } & CC & 172 & 43.9 & 12.2 & 0.83 \\
\hline & $\overline{C A}$ & 90 & 45.0 & 13.6 & \\
\hline & $\overline{\mathrm{AA}}$ & 15 & 44.3 & 13.8 & \\
\hline & & Total 277 & 44.3 & 12.7 & \\
\hline \multirow[t]{4}{*}{ NOS3-298 } & GG & 120 & 44.4 & 12.6 & 0.83 \\
\hline & $\overline{\mathrm{GT}}$ & 135 & 43.9 & 12.4 & \\
\hline & $\overline{\Pi T}$ & 22 & 45.6 & 15.7 & \\
\hline & & Total 277 & 44.3 & 12.7 & \\
\hline \multirow[t]{4}{*}{$\overline{\text { EDN1 }}$} & GG & 159 & 43.5 & 12.8 & 0.15 \\
\hline & GT & 83 & 46.0 & 12.8 & \\
\hline & $\pi$ & 24 & 40.7 & 9.3 & \\
\hline & & Total 266 & 44.0 & 12.6 & \\
\hline
\end{tabular}

Some samples could not be genotyped, making the totals less than 278.

S4). All other genotypes were not associated with $\mathrm{FEV}_{1} \%$ predicted. The NOS3-298 TT genotype was associated with lower $\mathrm{KCO} \%$ predicted than GG or GT genotypes

Table 3 Correlation of clinical factors with RVSP in COPD patients with an RVSP measurement

\begin{tabular}{llll}
\hline Clinical Factor & Number & $\begin{array}{l}\text { Correlation } \\
(\mathbf{r})\end{array}$ & $\boldsymbol{P}$ value \\
\hline $\mathrm{PaO}_{2}$ Vs RVSP & 222 & -0.245 & $\mathbf{0 . 0 0 0 2 3}$ \\
\hline $\mathrm{PaCO}_{2}$ vs RVSP & 222 & 0.041 & 0.55 \\
\hline $\mathrm{FEV}_{1} \%$ predicted vs RVSP & 278 & -0.118 & $\mathbf{0 . 0 5 0}$ \\
\hline $\mathrm{KCO}$ percent predicted vs RVSP & 268 & -0.258 & $\mathbf{0 . 0 0 0 0 1 9}$ \\
\hline Age at recruitment vs RVSP & 278 & 0.117 & 0.050 \\
\hline Smoking history: pack years vs RVSP & 278 & -0.042 & 0.48 \\
\hline $\mathrm{FEV}, \mathrm{NC}$ ratio vs RVSP & 278 & -0.133 & $\mathbf{0 . 0 2 7}$ \\
\hline $\mathrm{BMI}$ vs RVSP & 278 & -0.115 & 0.055 \\
\hline
\end{tabular}

$(P=0.031)$ (see Additional file 1: Table S5). No other significant differences were found between genotypes and $\mathrm{KCO} \%$ predicted.

\section{Discussion}

Few previous studies have examined multiple polymorphisms in relation to $\mathrm{PH}$ associated with COPD. In our study we examined seven SNPs in six candidate genes which encode mediators that act on pulmonary vessels. We tested whether these SNPs were associated with RVSP, which is a measure of $\mathrm{PH}$. We found that patients with the NOS3-VNTR 4aa or 4ab genotype had significantly higher RVSPs than those with the NOS3-VNTR 4bb genotype. In contrast, a study of 42 COPD patients and 40 controls found that the NOS3VNTR 4bb genotype was associated with PH in COPD [13]. The smaller number of patients in their study 


\begin{tabular}{|c|c|c|c|c|c|}
\hline Gene & Genotypes & Number & $\begin{array}{l}\text { Mean } \mathrm{FEV}_{1} \% \\
\text { predicted }\end{array}$ & $\begin{array}{l}\text { Standard } \\
\text { Deviation }\end{array}$ & $P$ value \\
\hline \multirow[t]{4}{*}{ VEGFA } & GG & 246 & 48.7 & 21.0 & 0.23 \\
\hline & $\mathrm{GC}$ & 256 & 50.6 & 22.7 & \\
\hline & $\overline{C C}$ & 75 & 53.5 & 20.4 & \\
\hline & & Total 577 & & 21.7 & \\
\hline \multirow[t]{4}{*}{ NOS3-VNTR } & $4 \mathrm{bb}$ & 414 & 50.0 & 22.3 & 0.80 \\
\hline & $4 a b$ & 148 & 51.0 & 20.6 & \\
\hline & $4 \mathrm{aa}$ & 15 & 47.7 & 17.7 & \\
\hline & & Total 577 & & 21.7 & \\
\hline \multirow[t]{4}{*}{$A C E$} & $\|$ & 142 & 49.6 & 20.9 & 0.09 \\
\hline & $\overline{I D}$ & 283 & 48.8 & 21.9 & \\
\hline & $\overline{\mathrm{DD}}$ & 153 & 53.6 & 22.2 & \\
\hline & & Total 578 & & 21.8 & \\
\hline \multirow[t]{4}{*}{$\overline{S L C 6 A 4}$} & $\mathrm{LL}$ & 179 & 49.7 & 22.7 & 0.97 \\
\hline & $\overline{\mathrm{LS}}$ & 285 & 50.2 & 21.2 & \\
\hline & SS & 107 & 50.2 & 22.1 & \\
\hline & & Total 571 & & 21.8 & \\
\hline \multirow[t]{4}{*}{ PTGIS } & $\mathrm{CC}$ & 336 & 50.0 & 21.0 & 0.77 \\
\hline & $\overline{C A}$ & 200 & 49.9 & 22.8 & \\
\hline & $\overline{A A}$ & 42 & 52.4 & 23.1 & \\
\hline & & Total 578 & & 21.7 & \\
\hline \multirow[t]{4}{*}{ NOS3-298 } & GG & 258 & 50.1 & 21.0 & 0.61 \\
\hline & $\overline{\mathrm{GT}}$ & 276 & 50.9 & 22.8 & \\
\hline & $\overline{\pi T}$ & 41 & 47.4 & 18.3 & \\
\hline & & Total 575 & & 21.7 & \\
\hline \multirow[t]{4}{*}{$\overline{E D N 1}$} & GG & 322 & 50.0 & 22.4 & 0.77 \\
\hline & $\overline{\mathrm{GT}}$ & 178 & 50.6 & 21.3 & \\
\hline & $\pi$ & 42 & 47.9 & 19.1 & \\
\hline & & Total 542 & & 21.8 & \\
\hline
\end{tabular}

Some samples could not be genotyped, making the totals less than 580 .

raises the possibility of a type I error Further studies are required to validate our findings.

There have been conflicting functional studies of the NOS3-VNTR 4aa genotype and plasma nitrite and nitrate (NOx) levels. A study of 428 healthy Caucasian members of 108 nuclear families found significantly higher levels of plasma NOx associated with the 4aa genotype compared to the $4 \mathrm{bb}$ and $4 \mathrm{ab}$ genotypes [32]. However another study found that there was a strong association between plasma NOx levels and the NOS3-VNTR polymorphism in 413 healthy Japanese subjects, the subjects with the 4aa genotype having significantly lower NOx levels [33]. The discordant results between these two studies may be due to ethnicity or methodological differences in measuring NOx levels. The functional results from this second study would support our finding of the 4aa genotype (with potentially lower nitric oxide levels and therefore less vasodilatation) being associated with higher RVSP (higher vascular resistance). The exact functional mechanisms of how the VNTR, or a nearby SNP which is in linkage disequilibrium with it, affects either nitric oxide or vascular remodelling, needs further elucidation.

We identified a number of clinical factors as being significantly associated with elevated RVSP on univariate analysis. These factors are well-known clinical markers of severity of COPD, and would be expected to correlate with elevated RVSP, since PH is related to COPD severity [31]. The NOS3-VNTR polymorphism was significantly associated with RVSP, and remained so when controlling for these factors.

Considering potential links between COPD severity and $\mathrm{PH}$, we examined the effect of SNPs in relation to respiratory function tests. Patients with the ACE II or ID genotypes showed a statistically significantly lower $\mathrm{FEV}_{1} \%$ predicted, albeit a clinically small difference, than the $A C E \mathrm{DD}$ genotypes. Analysis of the other genetic models for $A C E$ genotypes did not show associations. This is in contrast to a previous study of Caucasian Mediterraneans which found a higher frequency of $A C E \mathrm{DD}$ genotypes in 74 male smokers with COPD than in 77 male smokers with normal lung function (odds ratio 2.2) [34]. Additional studies are required to clarify this relationship.

Patients with the NOS3-298 TT genotype had significantly lower KCO than those with the GG or GT genotypes. Sun and co-workers' hypothesis [8] supports our results in that the lower NO levels associated with the TT genotype would potentially predispose those patients to greater lung tissue damage from cigarette smoke reflected in a reduced $\mathrm{KCO}$.

Potential limitations of this study should be considered. Two of the SNPs showed minor deviation in Hardy-Weinberg equilibrium, although these did not show positive associations. The reason for the minor deviation could include chance or differences in population sampling; we had performed repeat genotyping in $10 \%$ of samples and the results were concordant. In some COPD patients, RVSP measurement was not successful because of hyperinflated lungs causing a large retrosternal window, or because the tricuspid regurgitant jet was insufficient to enable calculation of RVSP. Use of echo contrast may have increased the yield of RVSP measurements in these cases. Given the exploratory nature of this study of 7 SNPs and RVSP in COPD, we did not correct for multiple comparisons, and the statistical significance of the results should be considered in light of this. Even with this relatively large cohort of patients, replication in other cohorts is needed. Functional analysis of polymorphisms 
Table 5 Association of genotype groups with KCO \% predicted, in COPD patients with a KCO measurement, using ANOVA

\begin{tabular}{|c|c|c|c|c|c|}
\hline Gene & Genotypes & Number & $\begin{array}{l}\text { Mean KCO } \\
\% \text { predicted }\end{array}$ & $\begin{array}{l}\text { Standard } \\
\text { Deviation }\end{array}$ & $P$ value \\
\hline \multirow[t]{4}{*}{ VEGFA } & GG & 241 & 58.4 & 23.0 & 0.88 \\
\hline & GC & 244 & 57.7 & 21.8 & \\
\hline & $\mathrm{CC}$ & 73 & 59.1 & 23.9 & \\
\hline & & Total 558 & & 22.6 & \\
\hline \multirow[t]{4}{*}{ NOS3-VNTR } & $4 \mathrm{bb}$ & 401 & 58.1 & 22.9 & 0.36 \\
\hline & $4 a b$ & 142 & 59.1 & 21.5 & \\
\hline & $4 a a$ & 15 & 50.3 & 24.5 & \\
\hline & & Total 558 & & 22.6 & \\
\hline \multirow[t]{4}{*}{$A C E$} & $\|$ & 136 & 60.3 & 24.9 & 0.42 \\
\hline & $\mathrm{ID}$ & 273 & 57.3 & 22.1 & \\
\hline & $\mathrm{DD}$ & 150 & 57.6 & 21.2 & \\
\hline & & Total 559 & & 22.6 & \\
\hline \multirow[t]{4}{*}{ SLC6A4 } & $\underline{\mathrm{LL}}$ & 176 & 58.0 & 22.4 & 0.84 \\
\hline & LS & 275 & 58.7 & 22.8 & \\
\hline & SS & 101 & 57.2 & 22.0 & \\
\hline & & Total 552 & & 22.5 & \\
\hline \multirow[t]{4}{*}{$\overline{P T G I S}$} & $\mathrm{CC}$ & 327 & 58.5 & 21.4 & 0.11 \\
\hline & CA & 192 & 56.2 & 23.8 & \\
\hline & $\underline{A A}$ & 40 & 64.3 & 25.0 & \\
\hline & & Total 559 & & 22.6 & \\
\hline \multirow[t]{4}{*}{ NOS3-298 } & GG & 250 & 58.5 & 24.0 & 0.10 \\
\hline & GT & 265 & 58.9 & 21.7 & \\
\hline & $\pi$ & 41 & 50.9 & 16.7 & \\
\hline & & Total 556 & & & \\
\hline \multirow[t]{4}{*}{ EDN1 } & GG & 310 & 57.5 & 22.4 & 0.17 \\
\hline & GT & 173 & 57.5 & 22.7 & \\
\hline & $\pi$ & 40 & 64.6 & 24.5 & \\
\hline & & Total 523 & & 22.7 & \\
\hline
\end{tabular}

Some samples could not be genotyped, making the totals less than 580 .

in model systems and genome-wide association studies of $\mathrm{PH}$ in COPD would be worthwhile in the future.

\section{Conclusions}

This study has shown a significant association between RVSP in COPD patients and the NOS3-VNTR 4aa or 4ab genotype. We also found associations between the $A C E$ II or ID genotypes and lower $\mathrm{FEV}_{1} \%$ predicted and the NOS3-298 TT genotype and lower KCO \% predicted. These results suggest that these polymorphisms may influence disease phenotype in COPD patients. Further study of these genes could lead to the development of prognostic and screening tools for $\mathrm{PH}$ in COPD, eventually leading to novel therapy targeting these pathways.

\section{Additional files}

Additional file 1 Table S1: Candidate genes and polymorphisms Table S2: Multiple regression analysis for RVSP. Table S3: Association of genotypes with RVSP measurements, using t-test. Table S4: Association of genotypes with FEV1\% predicted, using t-test. Table S5: Association of genotypes vs KCO percent predicted, using t-test.

\section{Competing interests}

The authors declare they have no competing interests.

\section{Authors' contributions}

IAY, JGS, RVB, PVZ and KMF designed the study and analysed data. JGS carried out the genotyping. JGS and LHP recruited and phenotyped patients. JGS and AGD carried out and interpreted lung function testing. DJB was responsible for the echocardiographs. JGS and IAY carried out the statistical analyses and interpretation of the data. JGS and IAY drafted the manuscript, and all authors contributed to and approved the manuscript. 


\section{Acknowledgments}

We sincerely thank the patients and staff of The Prince Charles Hospital for their participation in this study. We acknowledge funding support from The Prince Charles Hospital Foundation, NHMRC Career Development Award (IY) and NHMRC Practitioner Fellowship (KF).

\section{Author details}

'Department of Thoracic Medicine, The Prince Charles Hospital, Rode Rd, Chermside, Brisbane QLD 4032, Australia. ${ }^{2}$ Department of Echocardiography, The Prince Charles Hospital, Rode Rd, Chermside, Brisbane QLD4032, Australia. ${ }^{3}$ School of Medicine, The University of Queensland, St Lucia, Brisbane QLD4067, Australia.

Received: 4 November 2011 Accepted: 28 May 2012

Published: 13 June 2012

\section{References}

1. Minai OA, Chaouat A, Adnot S: Pulmonary hypertension in COPD: epidemiology, significance, and management: pulmonary vascular disease: the global perspective. Chest 2010, 137 (6 Suppl):39S-51S.

2. Weitzenblum E, Sautegeau A, Ehrhart M, Mammosser M, Hirth C, Roegel E: Long-term course of pulmonary arterial pressure in chronic obstructive pulmonary disease. Am Rev Respir Dis 1984, 130(6):993-998.

3. Kessler R, Faller M, Weitzenblum E, Chaouat A, Aykut A, Ducolone A, Ehrhart M, Oswald-Mammosser M: "Natural history" of pulmonary hypertension in a series of 131 patients with chronic obstructive lung disease. Am J Respir Crit Care Med 2001, 164(2):219-224.

4. Jyothula S, Safdar Z: Update on pulmonary hypertension complicating chronic obstructive pulmonary disease. Int J Chron Obstruct Pulmon Dis 2009, 4:351-363.

5. Chaouat A, Savale L, Chouaid C, Tu L, Sztrymf B, Canuet M, Maitre B, Housset B, Brandt C, Le CP, et al: Role for interleukin-6 in COPD-related pulmonary hypertension. Chest 2009, 136(3):678-687.

6. Ulrich S, Hersberger M, Fischler M, Nussbaumer-Ochsner Y, Treder U, Russi EW, Speich R: Genetic polymorphisms of the serotonin transporter, but not the 2a receptor or nitric oxide synthetase, are associated with pulmonary hypertension in chronic obstructive pulmonary disease. Respiration; international review of thoracic diseases 2010, 79(4):288-295.

7. Castaldi PJ, Hersh CP, Reilly JJ, Silverman EK: Genetic associations with hypoxemia and pulmonary arterial pressure in COPD. Chest 2009, 135 (3):737-744

8. Sun $L R$, Wang $C$, Wu AQ, Yan BM, Li DM, Zhang JL, Wang GJ, Zhang Y, Li $X Q$, Zhang QZ: Gene polymorphism of the endothelial nitric oxide synthase enzyme and pulmonary hypertension in patient with chronic obstructive pulmonary disease. Zhonghua Jie He He Hu Xi Za Zhi 2008, 31 (5):335-340.

9. Eddahibi S, Chaouat A, Tu L, Chouaid C, Weitzenblum E, Housset B, Maitre B, Adnot S: Interleukin-6 gene polymorphism confers susceptibility to pulmonary hypertension in chronic obstructive pulmonary disease. Proc Am Thorac Soc 2006, 3(6):475-476.

10. Tkacova R, Joppa P, Stancak B, Salagovic J, Misikova S, Kalina I: The link between angiotensin-converting enzyme genotype and pulmonary artery pressure in patients with COPD. Wien Klin Wochenschr 2005, 117(56):210-214.

11. Ahsan A, Ram R, Baig MA, Pasha MA: ACE I allele and eNOS G allele crosstalk may have a role in chronic obstructive pulmonary disease. Clin Biochem 2004, 37(11):1037-1040.

12. Kanazawa H, Tateishi Y, Yoshikawa J: Acute effects of nifedipine administration in pulmonary haemodynamics and oxygen delivery during exercise in patients with chronic obstructive pulmonary disease: implication of the angiotensin-converting enzyme gene polymorphisms. Clin Physiol Funct Imaging 2004, 24(4):224-228.

13. Yildiz P, Oflaz H, Cine N, Erginel-Unaltuna N, Erzengin F, Yilmaz V: Gene polymorphisms of endothelial nitric oxide synthase enzyme associated with pulmonary hypertension in patients with COPD. Respir Med 2003, 97 (12):1282-1288.

14. Eddahibi S, Chaouat A, Morrell N, Fadel E, Fuhrman C, Bugnet AS, Dartevelle P, Housset B, Hamon M, Weitzenblum E, et al: Polymorphism of the serotonin transporter gene and pulmonary hypertension in chronic obstructive pulmonary disease. Circulation 2003, 108(15):1839-1844.
15. Kanazawa H, Hirata K, Yoshikawa J: Effects of captopril administration on pulmonary haemodynamics and tissue oxygenation during exercise in ACE gene subtypes in patients with COPD: a preliminary study. Thorax 2003, 58(7):629-631.

16. Kanazawa H, Otsuka T, Hirata K, Yoshikawa J: Association between the angiotensin-converting enzyme gene polymorphisms and tissue oxygenation during exercise in patients with COPD. Chest 2002, 121 (3):697-701.

17. Kanazawa H, Okamoto T, Hirata K, Yoshikawa J: Deletion polymorphisms in the angiotensin converting enzyme gene are associated with pulmonary hypertension evoked by exercise challenge in patients with chronic obstructive pulmonary disease. Am J Respir Crit Care Med 2000, 162(4 Pt 1):1235-1238.

18. van Suylen RJ, Wouters EF, Pennings HJ, Cheriex EC, van Pol PE, Ambergen AW, Vermelis AM, Daemen MJ: The DD genotype of the angiotensin converting enzyme gene is negatively associated with right ventricular hypertrophy in male patients with chronic obstructive pulmonary disease. Am J Respir Crit Care Med 1999, 159 (6):1791-1795.

19. Nakayama T, Soma M, Saito S, Honye J, Yajima J, Rahmutula D, Kaneko Y Sato M, Uwabo J, Aoi N, et al: Association of a novel single nucleotide polymorphism of the prostacyclin synthase gene with myocardial infarction. Am Heart J 2002, 143(5):797-801.

20. Watson CJ, Webb NJ, Bottomley MJ, Brenchley PE: Identification of polymorphisms within the vascular endothelial growth factor (VEGF) gene: correlation with variation in VEGF protein production. Cytokine 2000, 12(8):1232-1235.

21. Global strategy for the diagnosis, management, and prevention of chronic obstructive pulmonary disease. [www.goldcopd.com/].

22. Miller MR, Crapo R, Hankinson J, Brusasco V, Burgos F, Casaburi R, Coates A Enright $P$, van der Grinten CP, Gustafsson P, et al: General considerations for lung function testing. Eur Respir J 2005, 26(1):153-161.

23. Miller MR, Hankinson J, Brusasco V, Burgos F, Casaburi R, Coates A, Crapo R, Enright $P$, van der Grinten $C P$, Gustafsson P, et al: Standardisation of spirometry. Eur Respir J 2005, 26(2):319-338.

24. Macintyre N, Crapo RO, Viegi G, Johnson DC, van der Grinten CP, Brusasco $V$, Burgos F, Casaburi R, Coates A, Enright $P$, et al: Standardisation of the single-breath determination of carbon monoxide uptake in the lung. Eur Respir J 2005, 26(4):720-735.

25. Morris JF, Koski A, Johnson LC: Spirometric standards for healthy nonsmoking adults. Am Rev Respir Dis 1971, 103(1):57-67.

26. Cotes JE: Lung Function. London: Blackwell Scientific Publications; 1993.

27. Celli BR, Thomas NE, Anderson JA, Ferguson GT, Jenkins CR, Jones PW, Vestbo J, Knobil K, Yates JC, Calverley PM: Effect of pharmacotherapy on rate of decline of lung function in chronic obstructive pulmonary disease: results from the TORCH study. Am J Respir Crit Care Med 2008, 178(4):332-338.

28. Lang RM, Bierig M, Devereux RB, Flachskampf FA, Foster E, Pellikka PA, Picard MH, Roman MJ, Seward J, Shanewise JS, et al: Recommendations for chamber quantification: a report from the American Society of Echocardiography's Guidelines and Standards Committee and the Chamber Quantification Writing Group, developed in conjunction with the European Association of Echocardiography, a branch of the European Society of Cardiology. J Am Soc Echocardiogr 2005, 18 (12):1440-1463.

29. Miller SA, Dykes DD, Polesky HF: A simple salting out procedure for extracting DNA from human nucleated cells. Nucleic Acids Res 1988, 16 (3):1215

30. Dupont WD, Plummer WD Jr: Power and sample size calculations. A review and computer program. Control Clin Trials 1990, 11(2):116-128.

31. Higham MA, Dawson D, Joshi J, Nihoyannopoulos P, Morrell NW: Utility of echocardiography in assessment of pulmonary hypertension secondary to COPD. Eur Respir J 2001, 17(3):350-355.

32. Wang XL, Mahaney MC, Sim AS, Wang J, Blangero J, Almasy L, Badenhop RB, Wilcken DE: Genetic contribution of the endothelial constitutive nitric oxide synthase gene to plasma nitric oxide levels. Arterioscler Thromb Vasc Biol 1997, 17(11):3147-3153.

33. Tsukada T, Yokoyama K, Arai T, Takemoto F, Hara S, Yamada A, Kawaguchi Y, Hosoya T, Igari J: Evidence of association of the ecNOS gene polymorphism with plasma NO metabolite levels in humans. Biochem Biophys Res Commun 1998, 245(1):190-193. 
34. Busquets $X$, MacFarlane NG, Heine-Suner D, Morla M, Torres-Juan L, Iglesias A, Llado J, Sauleda J, Agusti AG: Angiotensin-converting-enzyme gene polymorphisms, smoking and chronic obstructive pulmonary disease. Int J Chron Obstruct Pulmon Dis 2007, 2(3):329-334.

doi:10.1186/1471-2466-12-25

Cite this article as: Shaw et al:: Genetic influences on right ventricular systolic pressure (RVSP) in chronic obstructive pulmonary disease (COPD). BMC Pulmonary Medicine 2012 12:25.

\section{Submit your next manuscript to BioMed Central and take full advantage of:}

- Convenient online submission

- Thorough peer review

- No space constraints or color figure charges

- Immediate publication on acceptance

- Inclusion in PubMed, CAS, Scopus and Google Scholar

- Research which is freely available for redistribution 